\title{
Comparative Analysis of the Solid Waste Emissions between the Industrialized and Traditional Residential Building
}

\begin{abstract}
This paper aims at analyzing the solid waste emission issues between the industrialized and traditional residential building. The evaluation system of such rubble waste from construction and demolition (C\&D waste), including evaluation index and model was proposed based on the "whole life cycle" comprehensive evaluation method. The empirical study was applied using a steel structure industrial type of construction, applied to a residential building and comparing against the traditional construction of such dwelling. The result shows that the industrial construction is an effective way to protect the environment.
\end{abstract}

Keywords: industrialized housing, steel structure, solid waste emission, $\mathrm{C} \& \mathrm{D}$ waste, comprehensive evaluation method

\section{Introduction}

The average life expectancy of building is more than 80 years in Europe and America, especially reaches 132 years in the United Kingdom. By contrast, this index in China is only 30 years, which is less than $50 \%$ of the minimum of the international standard. Two world records, including the highest consumption of cement and steel and the largest production of construction garbage were created in China. The garbage reached 400 million tons per annum and made up $30 \%-40 \%$ of the total (Qiu, 2010). The solid waste, or the rubble waste from construction and demolition (C\&D waste), buried and exposed to the city, not only caused land occupation, corrosion of land surface and pollution of

Manuscript received September 4, 2014; accepted January 11, 2015

Wei Chen ( $₫)$, Wen Zeng, Jin Yan

School of Civil Engineering and Architecture, Wuhan University of Technology, Wuhan 430070, China

Email:15623245782@163.com;122670419@qq.com

Ming-de Tong

Wuhan Construction Energy-Saving Management Office, Wuhan 430070, China underground water, which brought terrible risks to the environment, but also destroyed urban appearance and weakened cultural heritage of China.

Take a city in central as an example. $C \& D$ waste caused by house building and dismantling during massive construction increases year upon year, while the resource recycling system is still in a low level. Studies have shown that demolishing an $1 \mathrm{~m}^{2}$ house will bring about $1.35 \mathrm{t}$ of rubble and $10,000 \mathrm{~m}^{2}$ construction will bring 500-600t of waste materials (Wang \& Zhao, 2004). The emissions of such solid waste in the city from 2004 to 2013 are shown in Figure 1 (Wuhan Bureau of Statistics, 2013). The result shows that production of solid waste in the city has been rising generally, but the defective recycling system, worsens the problem of solid waste.

The industrialized housing system offers an innovative alternative for many developing countries in response to the urgent demand for rapid and economically viable massproduced dwellings and severe environmental pollution by introducing developed manufacturing method. Mokhtar and Mahmood considered that the use of prefabrication was one of the most effective waste minimization methods in the construction industry (Mokhtar \& Mahmood, 2008). Thus the industrial construction should be developed urgently to solve the construction materials and waste problem. Such researches on dense rubble waste emission of residential construction mostly concentrated on qualitative analysis and rough estimate, and lacked comparative analysis of distinct structural systems. So it is necessary to accurately calculate and analyze solid waste emission of different types of housing.

\section{Analysis on solid waste emissions of residential building in a life cycle}

\subsection{Industrialized housing}

Steel structure is the principle style of industrial housing with an exterior envelope system comprising of new renewable wall brick and interior isolation system made of various composite wall panels and pre-manufactured 


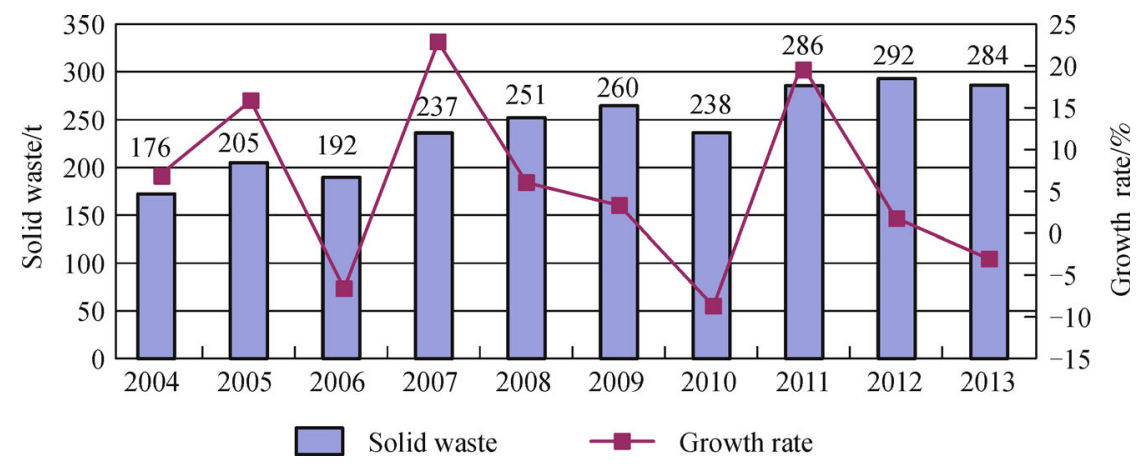

Figure 1. Residential solid waste generation of a city in central China (t).

reinforced concrete floor or situ commodity concrete floor (Xie, 2002). Steel is used as the main building material of industrialized housing, perfectly matches the principles of "Circular Economy" and meets the requirements of energy saving and environmental protection. Industrial construction with the characteristics of pre-manufacturing components, fabrication and high performance of recycle has advantages at reducing time, solid waste, water consumption, carbon emissions, and noise pollution onsite.

2.2 The sources of residential solid waste in the whole life cycle

The life cycle of residence, namely the entire process of residential products "from cradle to grave", includes exploitation of raw materials, production of building materials and equipments, manufacture of components, construction and installation, operation and maintenance, demolition. The process is accompanied by a variety of resource's occupancy and waste emissions. Residential life cycle is divided into three phases: materialization phase, operation phase and demolition and disposal phase. The sources of solid waste, at each phase, are shown in Table 1.

\subsection{Inventory analysis based on the theory of energy}

The paper uses process-based inventory analysis. It divides the system into a series of processes or activities within its boundaries, and then establishes the corresponding data list by the analysis of input and output of the unit process or activity, according to the inherent relationship between the system and each unit process or activity; input and output list will be set up and illustrated by function units (Huij- bregts, Hertwich, \& Reijnders, 2006). The inventory analysis of a unit process is shown in Figure 2. Solar energy is selected to unified different types of residential solid waste in the paper through the energy theory.

\section{Calculating model for solid waste emissions of residence}

The life cycle of residence is accompanied by a great amount of C\&D waste emission. Data from exploitation of raw materials and production of building materials are unavailable for the paper; the amount of solid waste emissions from phase of operation is small. Only data from phases of construction and demolition are considered during calculation. Therefore, the model includes two parts.

$$
S W=S W_{\mathrm{c}}+S W_{\mathrm{d}}
$$

$S W$ is the solid waste emission in life cycle. $S W_{\mathrm{c}}$ is the solid waste emission in construction. $S W_{\mathrm{d}}$ is the solid waste emission in demolition.

\subsection{The phase of construction}

The losses of materials from imperfect construction technology and management are the main resource of solid waste emission in this phase; the calculating model is shown as following.

$$
S W_{\mathrm{c}}=\sum_{i=1}^{n} m_{i} \times \sigma_{i} \times S T E_{i}
$$

$m_{i}$ is the quality of the $i$-th material and its unit is kg. $\sigma_{i}$ is

\section{Table 1}

The Sources of Residential Solid Waste in the Whole Life Cycle

\begin{tabular}{ccccc}
\hline \multicolumn{2}{c}{ Materialization phase } & Operation phase & \multicolumn{2}{c}{ Demolition \& disposal phase } \\
\cline { 1 - 1 } \cline { 5 - 6 } & Construction & & Demolition & Disposal \\
\hline $\begin{array}{l}\text { Losses from production of } \\
\text { materials and components }\end{array}$ & $\begin{array}{c}\text { Losses from construction } \\
\text { or mismanagement }\end{array}$ & $\begin{array}{c}\text { Solid waste from repair } \\
\text { or maintenance }\end{array}$ & $\begin{array}{c}\text { Solid waste from non- } \\
\text { recyclable building materials }\end{array}$ & $\begin{array}{c}\text { Disposal of recyclable } \\
\text { materials }\end{array}$ \\
\hline
\end{tabular}




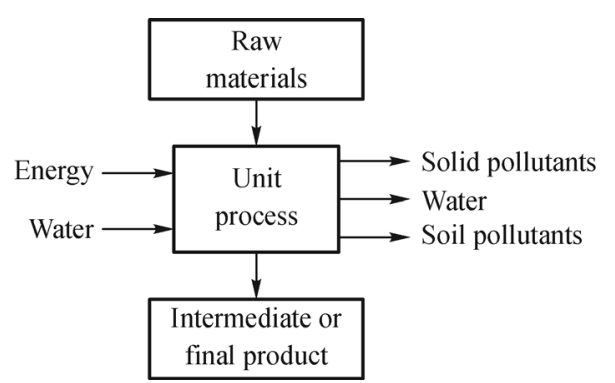

Figure 2. Inventory analysis based on a process.

the waste rate of the $i$-th material in construction. $S T E_{i}$ is the solar energy conversion rate of the $i$-th material, and its unit is $\mathrm{sej} / \mathrm{kg}$. Common data of building materials are shown in Table 2.

\subsection{The phase of demolition}

Non-recyclable waste materials are the main resource of solid waste emission in the phase, the model is shown as following.

$$
S W_{d}=\sum m_{i} \times\left(1-\rho_{i}\right) \times S T E_{i}
$$

$\rho_{i}$ is the recovery rate of waste materials. Data are shown in Table 3.

\section{Case study}

4.1 Selection of variables and data

Nearly 15 kinds of major and commonly used building materials are selected as analysis objects, including commercial concrete, cement, materials of wall and floor, steel, sand, glass, stone, other metals, paints and various non-metallic pipe. A steel structure house (\#1 House) and a reinforced concrete structure house (\#2 House) in central China are taken as examples.

The two buildings are relatively close in orientation and size, and their leading features are shown in Table 4. A list of main building materials of the house is obtained based on the construction drawings and budget documents of \#1 House and \#2 House. Data is shown in Table 5 and Table 6.

\subsection{Calculation result}

Plenty of solid waste is generated in construction phase because of imperfect construction technology. Demolition

Table 2

Common Data of Building Materials

\begin{tabular}{lccc}
\hline Building materials & Density $/\left(\mathrm{kg} \cdot \mathrm{m}^{-3}\right)$ & Waste rate $/ \%$ & STE \\
\hline Commercial concrete $/ \mathrm{m}^{3}$ & $1,900-2,500$ & 5 & $5.08 \times 10^{11} \mathrm{sej} / \mathrm{kg}$ \\
Cement $/ \mathrm{kg}$ & 3,100 & 5 & $3.3 \times 10^{13} \mathrm{sej} / \mathrm{kg}$ \\
Block $/ \mathrm{m}^{3}$ & $901-1,100$ & 10 & $5.08 \times 10^{11} \mathrm{sej} / \mathrm{kg}$ \\
Clay $/ \mathrm{m}^{3}$ & $1,600-1,800$ & 5 & $2.0 \times 10^{12} \mathrm{sej} / \mathrm{kg}$ \\
Steel $/ \mathrm{kg}$ & 7,850 & 5 & $1.4 \times 10^{12} \mathrm{sej} / \mathrm{kg}$ \\
Iron $/ \mathrm{kg}$ & 7,000 & 5 & $8.6 \times 10^{11} \mathrm{sej} / \mathrm{kg}$ \\
Glass $/ \mathrm{m}^{3}$ & 2,500 & 5 & $8.4 \times 10^{11} \mathrm{sej} / \mathrm{kg}$ \\
Brick $/ \mathrm{m}^{3}$ & 2,431 & 10 & $2.0 \times 10^{12} \mathrm{sej} / \mathrm{kg}$ \\
Granite $/ \mathrm{m}^{3}$ & $2,630-2,750$ & 5 & $5.0 \times 10^{5} \mathrm{sej} / \mathrm{kg}$ \\
Timber $/ \mathrm{kg}$ & $440-766$ & 5 & $6.9 \times 10^{11} \mathrm{sej} / \mathrm{kg}$ \\
Sand $/ \mathrm{m}^{3}$ & $2,550-2,750$ & 5 & $1.1 \times 10^{7} \mathrm{sej} / \mathrm{kg}$ \\
Waterproofing $/ \mathrm{m}^{2}$ & 0.7 & 5 & $4.3 \times 10^{12} \mathrm{sej} / \mathrm{kg}$ \\
Paint $/ \mathrm{CNY}$ & & 5 & $7.93 \times 10^{11} \mathrm{sej} / \mathrm{CNY}$ \\
Non-metallic pipes/CNY & & 5 & $7.93 \times 10^{11} \mathrm{sej} / \mathrm{CNY}$ \\
\hline
\end{tabular}

Note: adapted from Liu \& Zhao (2012).

Table 3

The Recovery Rate of Waste Building Materials

\begin{tabular}{lc||lc}
\hline Building materials & Recovery rate & Building materials & \multicolumn{1}{l}{ Recovery rate } \\
\hline Steel & 0.95 & Concrete and cement & 0.1 \\
Wall materials & 0.6 & Non-ferrous metals & 0.9 \\
Glass & 0.8 & Timber & 0.1 \\
\hline
\end{tabular}


Table 4

Main Characteristics of Building

\begin{tabular}{lcc}
\hline Characteristics & \#1 House & \#2 House \\
\hline Structure & Steel structure & Reinforced concrete structure \\
Building area $/ \mathrm{m}^{2}$ & $26,169.33$ & $25,474.14$ \\
Eaves height $/ \mathrm{m}$ & 53.2 & 53.2 \\
Storey height $/ \mathrm{m}$ & 2.9 & 2.9 \\
Time $/ \mathrm{d}$ & 300 & 270 \\
\hline
\end{tabular}

Table 5

Consumption of Main Building Materials of the \# 1 House

\begin{tabular}{lc||lc}
\hline Building materials & The actual amount & Building materials & The actual amount \\
\hline Concrete $/ \mathrm{m}^{3}$ & $7,109.05$ & Cement $/ \mathrm{kg}$ & $1,386,119.20$ \\
Block $/ \mathrm{m}^{3}$ & $4,891.12$ & Clay $/ \mathrm{m}^{3}$ & 197.53 \\
Sand $/ \mathrm{m}^{3}$ & $4,208.41$ & Steel $/ \mathrm{kg}$ & $1,750,392.83$ \\
$\mathrm{Glass} / \mathrm{m}^{2}$ & $2,451.72$ & Iron $/ \mathrm{kg}$ & $24,147.33$ \\
Granite $/ \mathrm{m}^{2}$ & 42.13 & Gravel $/ \mathrm{m}^{3}$ & $1,370.90$ \\
Brick $/ \mathrm{m}^{2}$ & $2,846.56$ & Waterproofing $/ \mathrm{m}^{2}$ & $3,028.92$ \\
Timber $/ \mathrm{kg}$ & $156,729.30$ & Non-metallic pipes $/ \mathrm{CNY}$ & 43,554 \\
Latex paint/CNY & $43,031.06$ & &
\end{tabular}

Table 6

Consumption of Main Building Materials of the \# 2 House

\begin{tabular}{lc||lc}
\hline Building materials & The actual amount & Building materials & The actual amount \\
\hline Concrete $/ \mathrm{m}^{3}$ & $6,531.22$ & Cement $/ \mathrm{kg}$ & $1,228,430.69$ \\
Block $/ \mathrm{m}^{3}$ & $5,015.16$ & Clay $/ \mathrm{m}^{3}$ & 203.57 \\
Sand $/ \mathrm{m}^{3}$ & $3,719.27$ & Steel $/ \mathrm{kg}$ & $1,850,392.33$ \\
Glass $/ \mathrm{m}^{2}$ & $2,489.52$ & Iron $/ \mathrm{kg}$ & $14,011.31$ \\
Granite $/ \mathrm{m}^{2}$ & 22.03 & Latex paint $/ \mathrm{CNY}$ & $41,302.34$ \\
Brick $/ \mathrm{m}^{2}$ & $2,696.47$ & Waterproofing $/ \mathrm{m}^{2}$ & $2,690.25$ \\
Timber $/ \mathrm{kg}$ & $156,677.49$ & Non-metallic pipes $/ \mathrm{CNY}$ & $29,392.47$ \\
\hline
\end{tabular}

phase is the main process of the solid waste emissions. The calculation results are shown in Table 7 and Table 8.

\subsection{Analysis}

The composition of C\&D waste of the \#1 House and the \#2 House in the life cycle, is shown in the Table 9, by summarizing the solid waste emissions from the two phases. The result shows that both steel structure house and reinforced concrete structure house will produce large amounts of waste in life cycle. The 'Demolition Phase' is the biggest contributor. The amount of solid waste emissions, in the Demolition Phase, accounts for more than $90 \%$ of the total. The amount in Construction Phase accounts for less than $10 \%$ of the total. Thus waste recovery in demolition phase should be emphasized to reduce solid waste.
Solid waste generated from cement and concrete accounts for $94.25 \%$ of the total in the \#1 House and $93.12 \%$ in the \#2 House. A new type of recyclable material is urgently required to replace the cement and concrete. The amount of solid waste emissions per functional unit $\left(1 \mathrm{~m}^{2}\right.$ building area) in life cycle of the \#2 House is $6.8 \%$ less than that of the \#1 House. These results indicate that steel, is environmental-friendly material, and steel structure housing has certain advantages in reducing solid waste.

\section{Conclusions}

Industrialized residential building with the characteristics of pre-manufacturing components, fabrication and high performance of recycle, has the advantage at reducing C\&D waste. The calculating model for solid waste 
Table 7

The Solid Waste Emissions from the \#1 House

\begin{tabular}{lcccccc}
\hline \multirow{2}{*}{ Phases } & \multicolumn{5}{c}{ Materials } \\
\cline { 2 - 7 } & Cement & Concrete & Wall and floor & Steel & Glass \\
\hline Construction & $1.50 \times 10^{18}$ & $3.97 \times 10^{17}$ & $3.21 \times 10^{17}$ & $1.23 \times 10^{17}$ & $2.57 \times 10^{15}$ & $3.64 \times 10^{16}$ \\
Demolition & $2.70 \times 10^{19}$ & $7.20 \times 10^{18}$ & $1.50 \times 10^{18}$ & $1.26 \times 10^{17}$ & $5.09 \times 10^{15}$ & $8.96 \times 10^{16}$ \\
Total & $2.85 \times 10^{19}$ & $7.60 \times 10^{18}$ & $1.82 \times 10^{18}$ & $2.49 \times 10^{17}$ & $7.66 \times 10^{15}$ & $1.26 \times 10^{17}$ \\
Proportion & $74.41 \%$ & $19.84 \%$ & $4.75 \%$ & $0.65 \%$ & $0.02 \%$ & $0.33 \%$ \\
\hline
\end{tabular}

Table 8

The Solid Waste Emissions from the \#2 House

\begin{tabular}{|c|c|c|c|c|c|c|}
\hline \multirow{2}{*}{ Phases } & \multicolumn{6}{|c|}{ Materials } \\
\hline & Cement & Concrete & Wall and floor & Steel & Glass & Others \\
\hline Construction & $1.33 \times 10^{18}$ & $3.66 \times 10^{17}$ & $3.56 \times 10^{17}$ & $1.30 \times 10^{17}$ & $2.61 \times 10^{15}$ & $3.64 \times 10^{16}$ \\
\hline Demolition & $2.40 \times 10^{19}$ & $6.56 \times 10^{18}$ & $1.57 \times 10^{18}$ & $2.26 \times 10^{17}$ & $1.12 \times 10^{16}$ & $3.28 \times 10^{16}$ \\
\hline Total & $2.53 \times 10^{19}$ & $6.93 \times 10^{18}$ & $1.93 \times 10^{18}$ & $3.56 \times 10^{17}$ & $1.38 \times 10^{16}$ & $6.92 \times 10^{16}$ \\
\hline Proportion & $73.12 \%$ & $20.03 \%$ & $5.58 \%$ & $1.03 \%$ & $0.04 \%$ & $0.2 \%$ \\
\hline
\end{tabular}

Table 9

The Composition of Solid Waste Emissions from the Samples

\begin{tabular}{|c|c|c|c|c|c|c|}
\hline \multirow{3}{*}{ Structure } & \multicolumn{4}{|c|}{ The amount of solid waste at each phase } & \multirow{3}{*}{$\begin{array}{c}\text { The total amount of } \\
\text { solid waste } / \mathrm{kg}\end{array}$} & \multirow{3}{*}{$\begin{array}{l}\text { The amount of solid } \\
\text { waste emissions per } \\
\left.\text { functional unit/(sej } \cdot \mathrm{m}^{-2}\right)\end{array}$} \\
\hline & \multicolumn{2}{|c|}{ Construction } & \multicolumn{2}{|c|}{ Demolition phase } & & \\
\hline & $/$ sej & $/ \%$ & /sej & $/ \%$ & & \\
\hline Steel Structure & $2.19 \times 10^{18}$ & 6.33 & $3.24 \times 10^{19}$ & 93.67 & $3.46 \times 10^{19}$ & $1.36 \times 10^{15}$ \\
\hline $\begin{array}{l}\text { Reinforced concrete } \\
\text { structure }\end{array}$ & $2.38 \times 10^{18}$ & 6.21 & $3.59 \times 10^{19}$ & 93.79 & $3.83 \times 10^{19}$ & $1.46 \times 10^{15}$ \\
\hline
\end{tabular}

emissions, is established for case analysis, by the method of inventory analysis and energy analysis. The result shows that the amount of C\&D waste emissions, per functional unit $\left(1 \mathrm{~m}^{2}\right.$ building area) in the life cycle of the industrialized house, is $6.8 \%$ less than that of a traditional house. The amount of solid waste in Demolition Stage accounts for about $93 \%$ in the whole life cycle. Therefore, the key points for decreasing the demolition waste of traditional housing are to bring in the recyclable building materials, and promote the development of industrialized residential buildings to improve the recycling system of construction and especially demolition methods.

\section{References}

Liu, H., \& Zhao, Y. (2012). The study of pressure on environment from civil solid waste emissions in life cycle. Environmental Sciences, (5),
200-204

Huijbregts, M., Hertwich, E.G., \& Reijnders L. (2006). Including human health damages due to road traffic in life cycle assessment of dwellings. The International Journal of Life Cycle Assessment, 11, 64-71

Mokhtar, S.N., \& Mahmood, N.Z. (2008). Approach in construction industry: a study on prefabrication method as a tool for waste minimization. International Conference on Environmental Research and Technology (ICERT 2008), Malaysia

Qiu, B. (2010). The speech at the sixth International Conference on Green Building and Building Energy. Retrieved from http://news. sina.com.cn/c/2010- 04-05/231820011742.shtml

Wang, L., \& Zhao, Y. (2004). Disposal and Utilization of Construction Waste. Beijing: Chemical Industry Press

Wuhan Bureau of Statistics. (2013). Wuhan Real Estate Yearbook 2004 2013. Wuhan: Wuhan Press

Xie, Z. (2002). Systems Engineering of Industrialized House. Beijing: China Building Industry Press 